\title{
Effects of Cowpea Leaf Harvesting Initiation Time and Frequency on Tissue Nitrogen Content and Productivity of a Dual-purpose Cowpea-maize Intercrop
}

\author{
Mwanarusi Saidi, Francis M. Itulya, and Joseph N. Aguyoh \\ Department of Crops, Horticulture and Soils, Egerton University, P.O. Box \\ Njoro-Kenya \\ Mathieu Ngouajio ${ }^{1}$ \\ Michigan State University, Department of Horticulture, 428 Plant and Soil \\ Science Building, East Lansing, MI 48824
}

Additional index words. defoliation, intercropping, vegetable yield, grain yield, land equivalent ratios

\begin{abstract}
Cowpea [Vigna unguiculata (L.) Walp.] is an important component of most traditional cropping systems in the semiarid tropics. It provides both leaf vegetable and/ or grain. Dual-purpose production of cowpea is most common in subsistence farming systems. Little is, however, known about the effects of cowpea leaf harvesting on tissue nitrogen composition and productivity of most cowpea-based cropping systems. A fourseason study was carried out at the National Dry Land Research Center, Katumani, Kenya, to establish the effects of cowpea leaf harvesting initiation time and frequency on 1) tissue nitrogen content of cowpea and maize in a dual-purpose cowpea-maize intercropping systems; and 2) cowpea and maize yield and the overall productivity of a cowpea-maize intercrop measured by land equivalent ratio (LER). Cowpea leaf harvesting was initiated at 2,3, or 4 weeks after emergence (WAE) and continued at 7- or 14-day intervals until onset of flowering. Cowpea tissue nitrogen content was highest in the control treatment and lowest in cowpea subjected to leaf harvesting from 2 WAE or at 7-day intervals, whereas maize tissue nitrogen content showed the reverse trend. Harvesting cowpea leaves from 3 WAE or at 7-day intervals gave the highest leaf vegetable yield, whereas grain yields were highest when no leaf harvesting was done. Maize yields were significantly improved by harvesting of leaves of the companion cowpea. Harvesting cowpea leaves for use as leaf vegetable increased productivity per unit area of land as measured by LER with the highest productivity achieved when leaf harvesting was initiated at 4 WAE or done at a 14-day interval.
\end{abstract}

Cowpea [Vigna unguiculata (L.) Walp.] is one of the important food legumes and a valuable component of traditional cropping systems in semiarid tropics (Henriet et al., 1997; Mortimore et al., 1997). It makes a valuable

Received for publication 23 Nov. 2009. Accepted for publication $25 \mathrm{Jan} .2010$

This work is part of a $\mathrm{PhD}$ research project by Mwanarusi Saidi conducted under sponsorship of the Higher Education Program for Agricultural Development (HEPAD), a program funded by USAID. This part of the study was hosted by The Kenya National Dry Land Research Center, Katumani.

We thank the Departments of Horticulture of Egerton University, Kenya, and Michigan State University, East Lansing, for facilitation of key activities during the study period. We also acknowledge the technical help of Stephen Omambia and Samson Omolo who served as the main field assistants during this part of the study.

${ }^{1}$ To whom reprint requests should be addressed; e-mail ngouajio@msu.edu. contribution toward human food and livestock fodder. As human food, cowpea can provide both vegetable and grain. This dualpurpose character has made it an attractive crop where land is becoming scarce (Singh et al., 2003). Its shade tolerance characteristic makes it compatible as an intercrop with maize, millet, sorghum as well as with several plantation crops (Singh and Emechebe, 1998). These characteristics have made cowpea an important component of subsistence agriculture in the semiarid tropics of Africa, Latin America, and Southeast Asia.

In many cowpea-growing areas of Africa and Asia, the crop is mainly grown by smallscale farmers who practice intercropping to maximize productivity on their small land holdings. Thus, although monocrop cowpea is profitable, farmers plant cowpea in various types of intercropping systems (Singh et al., 2003). Under such cropping systems, cowpea not only offers diversification in available food stuffs, but also serves as a security crop in case of failure of the main crops.
Two main systems are commonly used in the production of cowpea. Where the crop is grown purely for vegetable production, the entire plant is uprooted at the three to five true leaf stage before the leaves become too mature and fibrous. In the case of dual-purpose production, sequential leaf harvests are made during the vegetative stage of the crop followed by seed harvesting at the end of the season. The latter system predominates with most subsistence growers who practice intercropping. However, there is paucity of information on the effects of leaf harvesting on nitrogen composition and subsequent productivity of most cowpea-cereal-based cropping systems.

Defoliation influences tissue nitrogen content and subsequent yields of companion crops in an intercrop system. Nyeko et al. (2004) recorded increased maize shoot nitrogen content and yield with increase in defoliation intensity of a companion alder crop. In contrast, alder shoot nitrogen content was significantly decreased with increase in defoliation intensity. No information is available on how tissue nitrogen content and yield of companion crops of a dual-purpose cowpea-maize intercrop are influenced by leaf harvesting initiation time and frequency of the cowpea component at its vegetative stage. Also, information is lacking on the effects of harvesting cowpea leaves at the vegetative stage of the crop on individual crop performance in a dual-purpose cowpea-maize intercropping system. Moreover, studies on cowpea-cereal-based intercropping systems have mostly concentrated on grain yield, ignoring the potential vegetable yields and how these yields could influence the overall productivity of such systems (Rao and Mathuva, 2000; Reda et al., 2005; Rusinamhodzi et al., 2006). The objectives of this study were, therefore, to determine the effects of leaf harvesting initiation time and frequency of cowpea on 1) tissue nitrogen content of companion crops in a dual-purpose cowpea-maize intercrop; and 2) cowpea and maize yield and the overall productivity of a cowpea-maize intercrop measured by land equivalent ratios (LER).

\section{Materials and Methods}

The study was conducted in a span of four seasons at the National Dry Land Research Center, Katumani, Machakos, in the Eastern Province of Kenya, beginning in the Short Rains of Nov. 2006 to Feb. 2007 and covering the Long Rains of Apr. to July 2007, Short Rains of Nov. 2007 to Feb. 2008, and Long Rains of Apr. to July 2008. The site was chosen because the Eastern Province of Kenya is the major cowpea-growing area of Kenya. Katumani lies at an altitude of $1575 \mathrm{~m}$ above sea level and latitude $1^{\circ} 35^{\prime} \mathrm{S}$ and $37^{\circ} 14^{\prime} \mathrm{E}$ in Agro-Ecological Zone 4 with Chromic Luvisols soil types (FAO-UNESCO, 1990). Rainfall pattern in the area is bimodal with "March Rains" between March and July and "October Rains" between October and February. Rainfall amounts and distribution recorded during the study period are shown in Table 1 . 
Table 1. Amount and distribution of rainfall $(\mathrm{mm})$ received during the study period.

\begin{tabular}{lcccccccrr}
\hline & \multicolumn{7}{c}{ Month } \\
\cline { 2 - 9 } Growing season & Nov. & Dec. & Jan. & Feb. & Apr. & May & June & July & Total \\
\hline 1 & 328.4 & 321.3 & 61.4 & 44.8 & - & - & - & - & 755.9 \\
2 & - & - & - & - & 143.9 & 41.7 & 2.7 & 26.8 & 215.1 \\
3 & 129.7 & 82.6 & 117.4 & 7.3 & - & - & - & - & 337.0 \\
4 & - & - & - & - & 122.6 & 4.5 & 0.3 & 1.3 & 128.7 \\
\hline
\end{tabular}

\section{Plant material}

The most popular cowpea cultivar, K80, and maize cultivar, Katumani Composite B, in the area were used in this study. 'K80' is a physiologically determinate dual-purpose cultivar with a sprawling growth habit and flowers in $\approx 50 \mathrm{~d}$ from emergence. 'Katumani Composite B' is a fast-growing open-pollinated maize cultivar, which is fairly short $(\approx 170 \mathrm{~cm}$ tall) and produces short cobs. It is a droughtescaping cultivar, flowering within 60 to $65 \mathrm{~d}$, maturing within 90 to $120 \mathrm{~d}$ and is well adapted to marginal rainfall areas. Cowpea and maize seeds used in the study were purchased from the Kenya Agricultural Research Institute-Katumani Seed Unit.

\section{Experimental design and treatment application}

The experiment was conducted as an unbalanced factorial experiment with two fixed factors and controls. The two factors were 1) time from crop emergence to leaf harvesting initiation (LHI); and 2) leaf harvesting frequency (LHF). Leaf harvesting was initiated at 2,3, or 4 weeks after emergence (WAE). Harvesting frequencies were at 7- or 14-d intervals and a control treatment, in which no leaf harvesting was done. Monocrop cowpea (with leaf harvesting done at the different LHI and LHF specified for the intercrop treatments) and monocrop maize plots were also included to facilitate computation of LERs. A randomized complete block design with three replications was used in each season. Individual plots in a block measured $4 \mathrm{~m} \times 6 \mathrm{~m}$ separated from each other by a 1-m buffer. In each plot, data were collected from the inner $3.4 \mathrm{~m} \times 4.8-\mathrm{m}$ area, leaving the outer rows as guard rows.

Leaf harvesting entailed manual picking of all young but fully expanded trifoliate leaves (usually pale green in color, smoother, and shinier than mature leaves) with petiole from each vine. This is the stage at which growers harvest cowpea leaves for vegetable use. Once initiated, leaf harvesting was continued in all noncontrol plots until the onset of flowering.

\section{Crop establishment and management}

Both cowpea and maize were planted at the onset of the rains. Cowpea was planted at a spacing of $60 \mathrm{~cm} \times 20 \mathrm{~cm}$, whereas maize was planted at a spacing of $120 \times 30 \mathrm{~cm}$. A maize row was sandwiched between cowpea rows and there were two cowpea rows between consecutive maize rows. With this arrangement, cowpea and maize densities were similar in both the intercrop treatments and in the included monocrop cowpea and maize plots. Two seeds were planted in each hill but after emergence, thinning was done leaving one seedling per hill. Before planting, each plot received a blanket application of $18 \mathrm{~kg}$ nitrogen and $20 \mathrm{~kg}$ phosphorus/ha supplied by diammonium phosphate $(18: 46: 0)$ at the rate of $100 \mathrm{~kg} \cdot \mathrm{ha}^{-1}$.

Once established, all other maintenance activities, including weeding and pest and disease management, were uniformly applied to all plots.

\section{Data collection}

Tissue nitrogen content. Cowpea and maize total tissue nitrogen contents were determined at crop maturity using the Kjeldahl method as described by Okalebo et al. (2002) and expressed as $\mathrm{mg} \cdot \mathrm{kg}^{-1}$ of plant tissue. Tissue samples analyzed comprised entire above-ground plant parts, including the grain.

Cowpea leaf vegetable yield. Leaf vegetable yield data were collected weekly on initiation of leaf harvesting in the different treatments. The total leaf vegetable weight for each treatment in each season was obtained by summing up the fresh leaf weights obtained for the given treatment at the different leaf harvesting dates and expressed in metric $\mathrm{t} \cdot \mathrm{ha}^{-1}$.

Cowpea and maize grain yield. These data were collected at the end of each season by harvesting all the cowpea grain from the data collection area of individual plots when $\approx 75 \%$ of the pods were dry. Maize was also harvested from individual plots when over $75 \%$ of the cobs were dry. Harvested grain was sun-dried to constant moisture content and then weighed. The obtained grain yields were expressed in $\mathrm{t} \cdot \mathrm{ha}^{-1}$.

Productivity per unit area of land. Leaf vegetable and grain yields obtained from the different plots were used to compute productivity per unit area of land measured by LER. This was done as described by Willey (1979):

$$
\mathrm{LER}=\mathrm{L}_{\mathrm{A}}+\mathrm{L}_{\mathrm{B}}
$$

where $\mathrm{L}_{\mathrm{A}}=$ relative yield $(\mathrm{RY})_{\text {cowpea }}=\left(\mathrm{R} \mathrm{Y}_{\text {cowpea leaf vegetable }}+\mathrm{RY} \mathrm{Y}_{\text {cowpea grain }}\right)$ $\mathrm{RY}_{\text {cowpea leaf vegetable }}=\frac{\text { Leaf vegetable yield of cowpea intercropped at a given LHI or LHF }}{\text { Leaf vegetable yield of cowpea monocrop at the same LHI or LHF }}$ and

$$
\mathrm{RY}_{\text {cowpea grain }}=\frac{\text { Grain yield of cowpea intercropped at a given LHI or LHF }}{\text { Grain yield of cowpea monocrop }}
$$

$\mathrm{L}_{\mathrm{B}}=$ relative yield $_{\text {maize }}=\frac{\text { Yield of maize intercropped at a given cowpea LHI or LHF }}{\text { Yield of maize monocrop }}$ 
Maize nitrogen content, on the other hand, was highest in maize in which the cowpea companion crop was leaf-harvested compared with control treatment with no leaf harvesting done to the cowpea companion crop (Table 3). Averaged over the four seasons, initiating leaf harvesting of the companion cowpea crop at 2 WAE or harvesting cowpea leaves at $7 \mathrm{~d}$ intervals resulted in the highest nitrogen content of the companion maize crop with the lowest tissue nitrogen content obtained in the control treatment. Within each season, maize tissue nitrogen content was also lower in the control treatment with no leaf harvesting done to the gen content tended to increase with decrease in time between crop emergence and first leaf harvest of the companion cowpea crop leaf harvesting frequency from the 14-d to 7-d interval leaf harvesting interval of the companion cowpea crop. also had a significant effect on tissue nitrogen content for both cowpea and maize. Nitrogen content in cowpea tissues was highest in Season 1 with no significant differences companion cowpea crop. Maize tissue nitrofrom 4 WAE to 2 WAE and with increase in

Averaged across LHI and LHF, seasons

noted in tissue nitrogen content of cowpea in the other seasons (Table 2). Maize tissue nitrogen content was on the other hand highest in Season 4 and lowest in Season 1 (Table 3).

\section{Cowpea yields}

Leaf vegetable yields. Cowpea leaf vegetable yields were influenced by leaf harvesting initiation time and frequency (Fig. 1). Season $\times$ LHF interaction was also significant. Higher leaf vegetable yields were obtained when leaf harvesting was initiated at 3 WAE compared with initiating leaf harvesting at 2 or $4 \mathrm{WAE}$ across and within seasons (Fig. 1). Starting leaf harvesting too early at $2 \mathrm{WAE}$ resulted in the lowest leaf vegetable yields in all seasons. The differences in leaf vegetable yields among the leaf harvesting initiation times were, however, significant only in Season 1.

Although season $\times$ LHF interaction was significant, harvesting cowpea leaves at 7-d intervals produced higher leaf yield than biweekly harvesting at 14-d intervals in all the seasons. The difference in vegetable yield for the two leaf harvesting frequencies was, however, not significant in Season 2 (Fig. 1).

Table 2. Effects of leaf harvesting initiation time (LHI) and frequency (LHF) on cowpea tissue nitrogen content $\left(\mathrm{mg} \cdot \mathrm{kg}^{-1}\right)$ at crop maturity in a dual-purpose cowpea-maize intercrop.

\begin{tabular}{lllccc}
\hline \multicolumn{5}{c}{ Season } \\
\hline LHI & 1 & 2 & 3 & 4 & \\
$\quad$ None & & & & & LHI means \\
$2 \mathrm{WAE}$ & $25.1^{\mathrm{z}}$ & 16.3 & 11.8 & 16.8 & $19.1 \mathrm{a}^{\mathrm{y}}$ \\
$3 \mathrm{WAE}$ & 23.6 & 15.1 & 15.3 & 15.3 & $17.3 \mathrm{c}$ \\
$4 \mathrm{WAE}$ & 23.5 & 15.6 & 16.3 & 15.6 & $17.7 \mathrm{bc}$ \\
$\quad$ Season means & 24.1 & 15.7 & 16.3 & 15.7 & $17.9 \mathrm{~b}$ \\
LHF & $24.1 \mathrm{f}$ & $15.7 \mathrm{~h}$ & $16.5 \mathrm{~g}$ & $15.8 \mathrm{~h}$ & - \\
None & & & & & LHF means \\
$7 \mathrm{~d}$ & $25.1^{\mathrm{z}}$ & 16.3 & 11.8 & 16.8 & $19.1 \mathrm{a}$ \\
14 d & 23.3 & 15.0 & 15.8 & 15.2 & $17.3 \mathrm{c}$ \\
Season means & 24.1 & 15.9 & 16.1 & 15.7 & $18.0 \mathrm{~b}$ \\
\hline
\end{tabular}

${ }^{\mathrm{z}}$ Season $\times$ leaf harvesting initiation time (LHI) or season $\times$ leaf harvesting frequency (LHF) interaction is not significant $(P \leq 0.05)$.

${ }^{\mathrm{y}}$ Within leaf harvesting initiation time (LHI) or leaf harvesting frequency (LHF), means followed by the same letter in a letter series are not significantly different $(P \leq 0.05)$.

$\mathrm{WAE}=$ weeks after emergence.

Table 3. Effects of leaf harvesting initiation time (LHI) and frequency (LHF) on maize tissue nitrogen content $\left(\mathrm{mg} \cdot \mathrm{kg}^{-1}\right)$ at crop maturity in a dual-purpose cowpea-maize intercrop.

\begin{tabular}{lllllc}
\hline & \multicolumn{5}{c}{ Season } \\
\hline LHI & 1 & 2 & 3 & 4 & \\
$\quad$ None & $10.2^{\mathrm{z}}$ & 11.1 & 11.1 & 12.0 & LHI means \\
2 WAE & 11.1 & 12.8 & 12.9 & 14.3 & $12.1 \mathrm{c}^{\mathrm{y}}$ \\
3 WAE & 11.4 & 12.5 & 12.5 & 13.6 & $12.5 \mathrm{a}$ \\
4 WAE & 10.5 & 11.6 & 11.5 & 12.8 & $11.6 \mathrm{~b}$ \\
Season means & $10.8 \mathrm{~h}$ & $12.0 \mathrm{~g}$ & $12.0 \mathrm{~g}$ & $13.2 \mathrm{f}$ & \\
LHF & & & & & LHF means \\
None & $10.2^{\mathrm{z}}$ & 11.1 & 11.1 & 12.0 & $11.1 \mathrm{c}$ \\
$7 \mathrm{~d}$ & 11.4 & 12.6 & 12.5 & 13.9 & $12.6 \mathrm{a}$ \\
14 d & 10.6 & 12.0 & 12.1 & 13.2 & $12.0 \mathrm{~b}$ \\
Season means & $10.7 \mathrm{~h}$ & $11.9 \mathrm{~g}$ & $11.9 \mathrm{~g}$ & $13.1 \mathrm{f}$ & \\
\hline
\end{tabular}

${ }^{{ }^{2}}$ Season $\times$ leaf harvesting initiation time (LHI) or season $\mathrm{x}$ leaf harvesting frequency (LHF) interaction is not significant $(P \leq 0.05)$.

${ }^{\mathrm{y}}$ Within leaf harvesting initiation time (LHI) or leaf harvesting frequency (LHF), means followed by the same letter in a letter series are not significantly different $(P \leq 0.05)$.

$\mathrm{WAE}=$ weeks after emergence.
Leaf vegetable yields were also influenced by seasonal variations with higher leaf vegetable yields obtained in Season 1 than in the other seasons.

Grain yields. Leaf harvesting caused a reduction in cowpea grain yield (Fig. 2). Except in Season 1 when higher grain yields were obtained when cowpea leaves were harvested beginning at 3 or $4 \mathrm{WAE}$, compared with the control treatment, cowpea grain yields tended to be higher in the control treatment in all the other seasons. Initiating leaf harvesting at 2 WAE resulted in the lowest cowpea grain yield in all the seasons. Among treatments subjected to leaf harvesting, grain yield tended to increase with increase in time between crop emergence and first leaf harvest, except in Season 1 when initiating leaf harvesting at $3 \mathrm{WAE}$ yielded slightly higher cowpea grain yield than initiating leaf harvesting at 4 WAE.

The most intensive LHF at 7-d intervals resulted in the greatest reduction in grain yield in all seasons, although significant only in Seasons 1 and 2 (Fig. 2). Overall, higher cowpea grain yield was obtained from control cowpea not subjected to leaf harvesting in all the seasons, except in Season 1, when grain yields from 14-d LHF treatment were slightly higher than of the control treatment.

Like the case with leaf vegetable yields, grain yields were also influenced by seasonal variations with higher grain yields obtained in Season 1 than in the other seasons.

\section{Maize grain yield}

Harvesting leaves of the companion cowpea in a cowpea-maize intercrop at the vegetative stage of the crop significantly increased maize grain yield (Fig. 3). Lower maize grain yields were obtained when maize was intercropped with cowpea whose leaves were not harvested compared with maize intercropped with cowpea subjected to leaf harvesting in all the seasons. No significant differences existed in maize grain yields when maize was intercropped with cowpea whose leaves were harvested from 2, 3, or 4 WAE in Seasons 2,3 , and 4, respectively. In Season 1, however, grain yields of maize intercropped with cowpea whose leaves were harvested beginning $3 \mathrm{WAE}$ were significantly higher than those from 2 and $4 \mathrm{WAE}$ treatments. Although maize grain yields were highest in treatments in which harvesting of leaves of the companion cowpea crop was initiated at 3 WAE in all other seasons, maize grain yield was highest when cowpea leaf harvesting was initiated at 2 WAE in Season 4.

Similarly, maize grain yields were highest when leaves of the companion cowpea crop were harvested more frequently and lowest in control treatment whose cowpea crop was not subjected to any leaf harvesting (Fig. 3).

Seasonal variation also affected maize grain yield. The highest maize grain yield was obtained in Season 3, whereas the lowest yield was obtained in Season 4 with no difference noted between grain yield of Seasons 1 and 2 . 

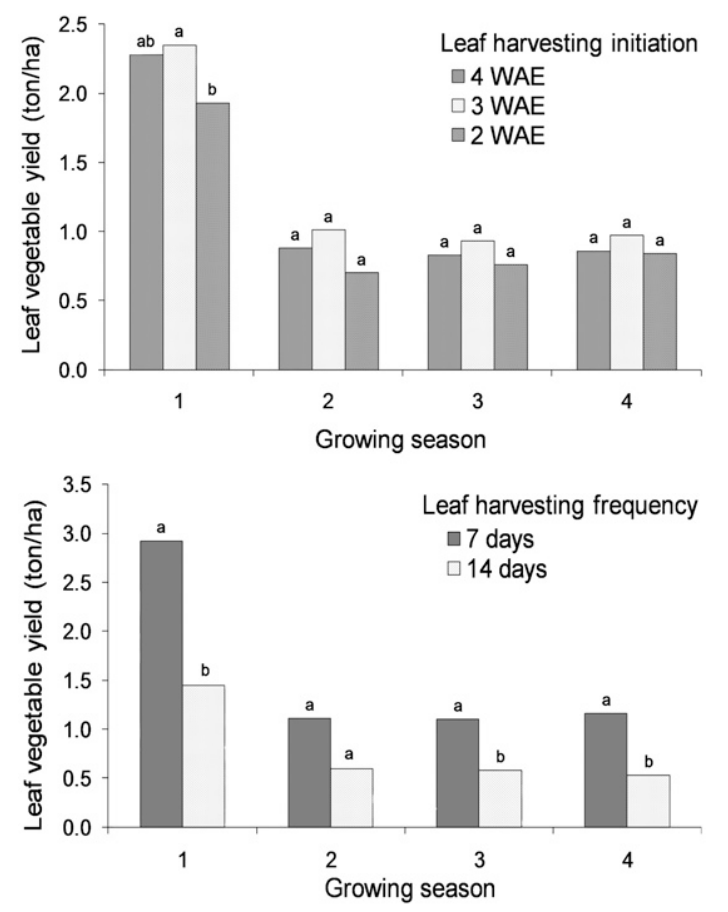

Fig. 1. Effects of cowpea leaf harvesting initiation time and frequency on leaf vegetable yield of a dualpurpose cowpea-maize intercrop in different seasons. Within a given season and leaf harvesting initiation time or frequency, bars with the same letter are not significantly different $(P<0.05)$.
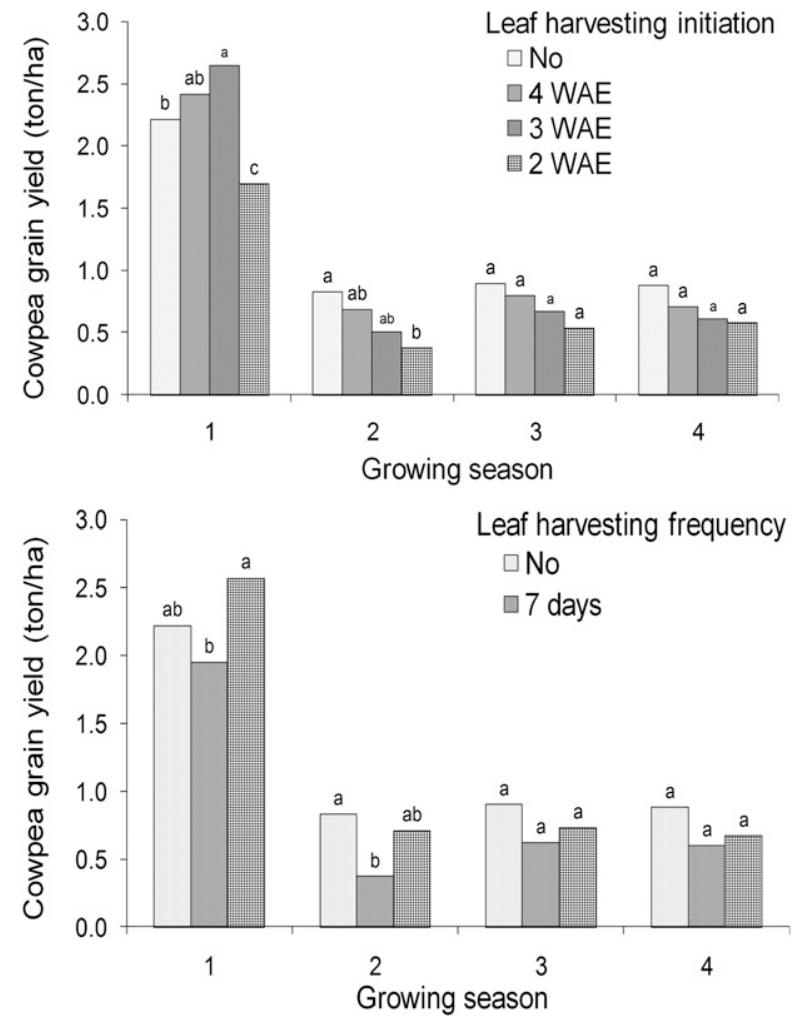

Fig. 2. Effects of cowpea leaf harvesting initiation time and frequency on cowpea grain yield of a dualpurpose cowpea-maize intercrop in different seasons. Within a given season and leaf harvesting initiation time or frequency, bars with the same letter are not significantly different $(P<0.05)$.

\section{Land equivalent ratios}

Intercropping a dual-purpose cowpea with maize increased productivity per unit area of land measured by LER (Table 4). LER values above unity were obtained under all intercrop treatments. Timing of leaf har- vesting initiation of the cowpea intercrop significantly influenced LER values compared with when no leaf harvesting was done (Table 4). Initiating leaf harvesting of the intercrop cowpea at 4 WAE gave the highest LER values of 2.04 followed by leaf harvest initiation at 3 WAE (1.94) and 2 WAE (1.78). The lowest LERs (1.01) were obtained when no leaf harvesting was done to the companion cowpea crop.

Leaf harvesting frequency also influenced LERs. Harvesting leaves of the cowpea intercrop every $14 \mathrm{~d}$ resulted in higher LERs (1.93) than when leaves were harvested every $7 \mathrm{~d}$ (1.89). The lowest LER was obtained from the cowpea-maize intercrop control treatments under which no leaf harvesting was done on the cowpea intercrop in all seasons (Table 4).

\section{Discussion}

The use of dual-purpose cowpea as components of intercropping systems offers great potential in meeting food requirements of many people. Both cowpea leaves and grain can contribute positively toward meeting the nutritional requirements of many resourcepoor families being high in protein. Realization of the potentials associated with dual-purpose cowpea-based production systems has been limited by the lack of adequate information on how leaf harvesting aspects impact on the performance of cowpea itself as well as the crops grown in association with the cowpea and the overall productivity per unit area of land in situations in which the dualpurpose cowpea is grown in an intercropping system.

Results of this study show that leaf vegetable and grain yields of dual-purpose cowpea intercropped with maize are influenced by leaf harvesting initiation time and frequency. Delaying leaf harvesting initiation from 2 WAE to $3 \mathrm{WAE}$ increases leaf vegetable yields. However, a further delay in initiation of leaf harvesting to 4 WAE leads to a decline in leaf vegetable yield (Fig. 1). The timing of leaf removal has great effects on the plant's ability to recover from leaf harvesting (Barrett, 1987). Initiating leaf harvesting at 2 WAE does not allow the plants ample time to develop good vegetative growth to permit adequate photosynthesis and subsequent recovery and growth of the plants. At $2 \mathrm{WAE}$, most of the plants are at the second true leaf stage with either of the leaves too young or at the right stage of leaf harvesting for consumption as leaf vegetables; thus, insufficient foliage is left on leaf harvesting to support subsequent biomass production. However, at $3 \mathrm{WAE}$ and beyond, the plants have formed lateral shoots and at least three fully expanded true leaves with some of the leaves past the consumable stage as leaf vegetable. This leaves the plant with adequate foliage to support photosynthesis that can sustain recovery and sufficient growth after leaf harvesting. Further delay in initiating leaf harvesting at $4 \mathrm{WAE}$, however, decreases the period between leaf harvesting initiation and flowering and the subsequent number of harvests that can be made. The reduced number of leaf harvests may also have accounted for the low leaf vegetable yield recorded for 4 WAE leaf harvesting initiation treatments. 

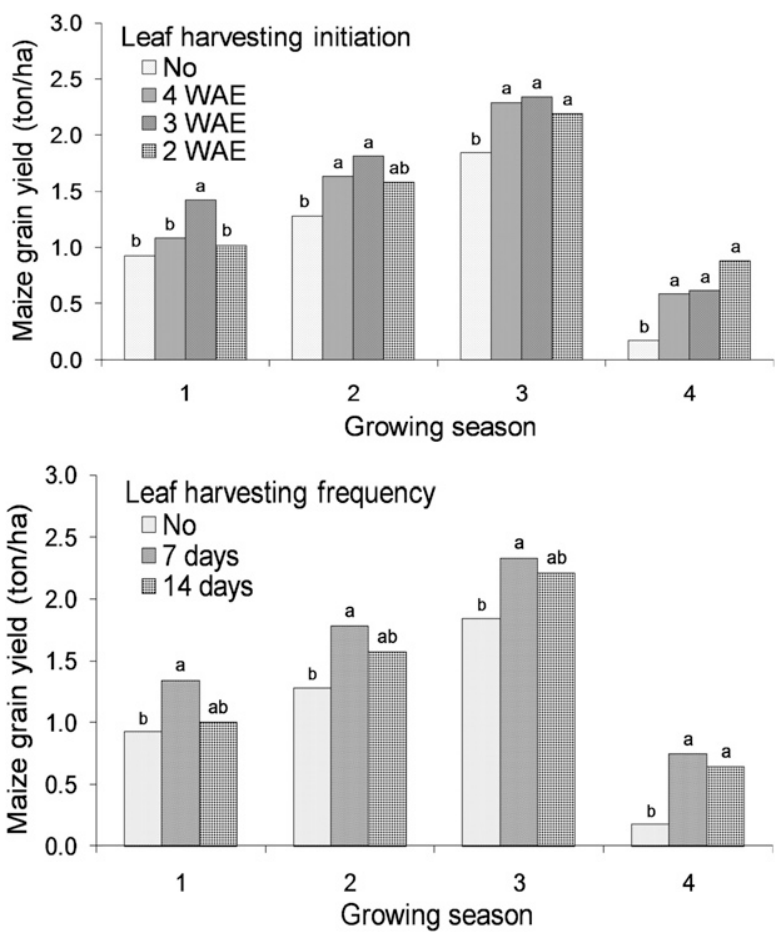

Fig. 3. Effects of cowpea leaf harvesting initiation time and frequency on maize grain yield of a dualpurpose cowpea-maize intercrop in different seasons. Within a given season and leaf harvesting initiation time or frequency, bars with the same letter are not significantly different $(P<0.05)$.

Table 4. Land equivalent ratios (LER) of intercropping cowpea with maize at varying cowpea leaf harvesting initiation time (LHI) and leaf harvesting frequency (LHF).

\begin{tabular}{|c|c|c|c|c|c|c|}
\hline & \multicolumn{4}{|c|}{ Relative yields } & & \\
\hline & Season & Cowpea & Maize & LER & & \\
\hline \multicolumn{5}{|c|}{ LHI [weeks after emergence (WAE)] } & $\begin{array}{l}\text { LHI } \\
\text { means }\end{array}$ & $\begin{array}{l}\text { Percent increase in } \\
\text { land productivity }\end{array}$ \\
\hline \multirow[t]{4}{*}{ None } & 1 & 0.58 & 0.30 & 0.88 & & \\
\hline & 2 & 0.59 & 0.65 & 1.24 & & \\
\hline & 3 & 0.50 & 0.58 & 1.08 & & \\
\hline & 4 & 0.76 & 0.09 & 0.85 & 1.01 & 1 \\
\hline \multirow[t]{4}{*}{$2 \mathrm{WAE}$} & 1 & 1.43 & 0.32 & 1.75 & & \\
\hline & 2 & 0.91 & 0.82 & 1.73 & & \\
\hline & 3 & 1.14 & 0.70 & 1.84 & & \\
\hline & 4 & 1.37 & 0.43 & 1.80 & 1.78 & 78 \\
\hline \multirow[t]{4}{*}{$3 \mathrm{WAE}$} & 1 & 1.64 & 0.45 & 2.09 & & \\
\hline & 2 & 1.05 & 0.93 & 1.98 & & \\
\hline & 3 & 1.17 & 0.75 & 1.92 & & \\
\hline & 4 & 1.48 & 0.30 & 1.78 & 1.94 & 94 \\
\hline \multirow[t]{4}{*}{$4 \mathrm{WAE}$} & 1 & 1.59 & 0.35 & 1.94 & & \\
\hline & 2 & 1.23 & 0.94 & 2.17 & & \\
\hline & 3 & 1.33 & 0.74 & 2.07 & & \\
\hline & 4 & 1.71 & 0.28 & 1.99 & 2.04 & 104 \\
\hline \multicolumn{6}{|l|}{ LHF } & LHF means \\
\hline \multirow[t]{4}{*}{ None } & 1 & 0.58 & 0.30 & 0.88 & & \\
\hline & 2 & 0.59 & 0.65 & 1.24 & & \\
\hline & 3 & 0.50 & 0.58 & 1.08 & & \\
\hline & 4 & 0.76 & 0.09 & 0.85 & 1.01 & 1 \\
\hline \multirow[t]{4}{*}{$7 d$} & 1 & 1.47 & 0.43 & 1.90 & & \\
\hline & 2 & 1.00 & 0.92 & 1.93 & & \\
\hline & 3 & 1.17 & 0.75 & 1.92 & & \\
\hline & 4 & 1.50 & 0.35 & 1.85 & 1.89 & 89 \\
\hline \multirow[t]{4}{*}{$14 \mathrm{~d}$} & 1 & 1.62 & 0.31 & 1.95 & & \\
\hline & 2 & 1.14 & 0.81 & 1.86 & & \\
\hline & 3 & 1.27 & 0.71 & 1.88 & & \\
\hline & 4 & 1.55 & 0.33 & 1.80 & 1.93 & 93 \\
\hline
\end{tabular}

On the other hand, leaf yields were higher under more frequent leaf harvesting ( $7 \mathrm{~d}$ ) than harvesting at 14-d intervals. Defoliation has been shown to stimulate leaf production in cowpea (Bubenheim et al., 1990). Higher leaf yields obtained under more frequent harvesting could have been a result of stimulation of leaf production. Low leaf yield from the 14-d harvest interval is also attributed to the fact that some of the leaves produced between harvest intervals would surpass the consumable stage before the next harvest. Only young and tender leaves are consumed as vegetable. Findings of this study are in agreement with those of an earlier study by Saidi et al. (2007), who observed that under greenhouse conditions, there was a decline in leaf vegetable yield of two cowpea varieties as leaf harvesting initiation was delayed from 4 to 5 WAE.

Cowpea grain yields were lower in leafharvested cowpea and higher in cowpea not subjected to any leaf harvesting, except in Season 1, when higher grain yields were obtained with 3 and 4 WAE leaf harvesting initiation times and 14-d leaf harvesting frequency compared with control cowpea (Fig. 2). Because during sequential harvests, only fully expanded tender leaves are harvested for consumption as leaf vegetables, delaying first leaf harvest or harvesting leaves less often left more leaves on the plants, offering a higher photosynthetic surface. Hence, there is better accumulation of carbon reserves for grain formation. Similarly, Karikari and Molatakgosi (1999) recorded higher grain yield with $50 \%$ defoliation compared with $75 \%$ defoliation of cowpea foliage during the growing season of the crop.

Apart from reduced photosynthetic surface after leaf harvesting, lower grain yield realized in leaf-harvested cowpea may also be associated with low tissue nitrogen levels recorded in these treatments. Photosynthesis is closely related to leaf nitrogen content with higher photosynthetic rates achieved when leaf nitrogen is not limiting (Evans, 1996). Young leaves typically have two to four times the nitrogen content of mature leaves (Coley and Aide, 1991). During sequential harvests, young tender leaves are harvested for vegetable use. In the process, leaf-harvested cowpea could thus have lost substantial amounts of nitrogen, hence the low tissue nitrogen contents recorded for these treatments compared with control.

Generally, cowpea was more vegetative and productive in Season 1 than in other seasons for all the treatments. Seasonwise variation in cowpea leaf vegetable and grain yield observed in this study could mainly be attributed to the variation in weather, particularly rainfall (Table 1). The highest leaf vegetable and grain yields were obtained in Season 1, the season during which the highest amount of rainfall $(755.9 \mathrm{~mm})$ with good distribution was received compared with $215.1 \mathrm{~mm}, 340 \mathrm{~mm}$, and $128.7 \mathrm{~mm}$ received in Seasons 2, 3, and 4, respectively. Also most of the rainfall in Seasons 2 and 4 was received within the first month. The importance of rainfall on the performance of rainfed agricultural systems cannot be overemphasized. Midya et al. (2005) recorded better performance of black gram and rice in seasons that received more rainfall with uniform distribution than in seasons that received less rain or uneven rain distribution. Favorable rainfall in Season 1 favored vegetative growth of cowpea and the lack of leaf 
removal in control plants may have resulted in increased competition for other growth factors like light with the competition being higher in nonleaf-harvested (control) than in leaf-harvested cowpea. This possibly accounted for the lower cowpea grain yields obtained from the control treatment compared with when leaf harvesting was initiated at 3 or 4 WAE and done at 14-d intervals in Season 1.

Harvesting leaves of the companion cowpea at the vegetative stage of the crop increased the grain yield of a companion maize crop in a cowpea-maize intercrop (Fig. 3). Harvesting leaves from cowpea plants reduced the cowpea canopy, which could have lowered nitrogen demand by the cowpea plants. This could have led to reduced between-species competition for available soil nitrogen in favor of maize, resulting in maize with higher tissue nitrogen contents that could have favored photosynthesis and higher grain production. High yields obtained in maize grown in association with leaf harvested cowpea compared with maize in control treatments may also have been as a result of reduced competition for other growth resources, especially light and water. Coupled with this, leaf harvesting also minimized the shading effect of cowpea on maize early in the season compared with the nonleaf-harvested control treatment, especially in seasons with high rainfall as was the case in Season 1 of our study (Table 1) or aided in reduction of water requirement of the cowpea crop in relatively dry seasons like in Season 4 , possibly explaining the varied response of maize in the different seasons as influenced by leaf harvesting. Similarly, Nyeko et al. (2004) recorded an increase in total biomass of maize by up to $209 \%$ with defoliation of a companion alder (Alnus acuminate) crop compared with maize grown in association with nondefoliated alder with highest shoot nitrogen content recorded in more intense defoliation treatments.

Tissue nitrogen content also showed seasonwise variation, being highest in the season that received the highest amount of rainfall (Season 1) and the one that received the least amount of rainfall (Season 4) in cowpea and maize, respectively. Cowpea tended to have faster establishment and early vegetative growth compared with maize, more so in Season 1 compared with other seasons. This may have favored the establishment of a good root system that may have facilitated better uptake of nitrogen from the soil by cowpea posing greater competition for available nitrogen on the maize crop. During relatively dry seasons (Seasons 4 and 2), cowpea establishment early in the season was slow, which could have given maize a better chance to compete for available soil nitrogen. These could possibly account for the seasonwise variation in maize and cowpea tissue nitrogen contents.

LERs answer the question, "How much land will be required to produce the amount of crop in a monocrop equal to those produced in a given unit of land under intercrop- ping?" LER greater than 1.0 is considered beneficial. Intercropping increases productivity per unit area (Adhikary et al., 1991; Rusinamhodzi et al., 2006). Our results support this argument. Results of this study also show that productivity of cowpea-maize intercrop can further be improved by harvesting of cowpea leaves for consumption as leaf vegetable at the vegetative stage of the crop (Table 4). When cowpea leaves were harvested and leaf vegetable yields included as part of cowpea yield from a given area of land, LERs increased by $78 \%, 94 \%$, and $104 \%$ under 2,3 , and 4 WAE leaf harvesting initiation times, respectively, and by $89 \%$ and $93 \%$ under $7-d$ and $14-d$ leaf harvesting frequencies, respectively, compared with when no leaf harvesting was done to the cowpea intercrop (1\%). From the results of this study, a cowpea-maize intercrop under which cowpea leaves are not harvested during the vegetative part of the plants tends to exhibit an inhibitory interaction, probably as a result of high competition for growth resources, leading to inadequate availability of growth factors to both component crops in such system. This argument is supported by the fact that relative yield values far below unity were obtained for both cowpea and maize in the nonleaf-harvested cowpeamaize intercrop treatments in all the seasons. Harvesting cowpea leaves at the vegetative stage of cowpea growth, however, tended to change this relationship from an inhibitory to a monopolistic interaction in favor of cowpea. Cowpea relative yields improved to above unity with all leaf-harvesting treatments, except in Season 2 when cowpea harvesting was initiated at 2 WAE (Table 4).

Based on the findings of this study, leaf harvesting initiation time and frequency influence tissue nitrogen content of companion cowpea and maize crops, cowpea leaf vegetable and grain yield, and grain yield of maize in a cowpea-maize intercrop system. Initiating cowpea leaf harvesting at 4 WAE or harvesting leaves at 14-d intervals gives higher grain yield among leaf-harvested cowpea with the no leaf harvesting control giving the highest grain yield. On the other hand, initiating leaf harvesting at $3 \mathrm{WAE}$ or harvesting leaves at 7-d intervals gives the highest cowpea leaf vegetable yields but grain yields are reduced. Leaf harvesting of a companion cowpea crop improves on maize yield in a cowpea-maize intercrop. Harvesting of cowpea leaves for use as leaf vegetable at the vegetative stage of the crop also increases productivity per unit area of land under a cowpea-maize intercrop with higher productivity achieved when leaf harvesting is initiated at 4 WAE or is done at a $14-\mathrm{d}$ interval.

Although results of this study provide a good foundation to understanding the effects of cowpea leaf harvesting initiation time and frequency on tissue nitrogen content of companion crops, leaf vegetable and grain yield of the dual-purpose cowpea itself, grain yield of an associated maize crop and productivity per unit area of land under a cowpea- maize intercrop, we suggest that additional studies on the subject should be conducted to establish changes in tissue nitrogen composition of companion crops at different stages of growth as influenced by leaf harvesting of the cowpea and correlate these changes to biomass production of the crops. Additional studies using different varieties/cultivars in different agroecological zones and cowpeabased cropping systems would also be useful. Finally, an economic analysis of the various production systems would supplement the information of system productivity presented in the current study.

\section{Literature Cited}

Adhikary, S., D.K. Bagchi, P. Ghosal, R.N. Banerjee, and B.N. Chatterjee. 1991. Studies on maizelegume intercropping and their residual effects on soil fertility status and succeeding crop in upland situation. J. Agron. Crop Sci. 167:289293.

Barrett, R.P. 1987. Integrating leaf and seed production strategies for cowpea [Vigna unguiculata (L.) Walp]. MS thesis, Michigan State Univ., East Lansing, MI.

Bubenheim, D.L., C.A. Mitchell, and S.S. Nielsen. 1990. Utility of cowpea foliage in crop production for space, p. 535-538. In: Janick, J. and J.E. Simon (eds.). Advances in new crops. Timber Press, Portland, OR.

Coley, P.D. and T.M. Aide. 1991. A comparison of herbivory and plant defenses in temperate and tropical broadleaved forests, p. 25-49. In: Prince, P.W., T.M. Lewinsohn, G.W. Fernandes, and W.W. Benson (eds.). Plant-animal interactions: Evolutionary ecology in tropical and temperate regions. John Wiley and Sons, New York, NY.

Evans, J.R. 1996. Developmental constraints on photosynthesis: Effects of light and nutrition, p. 281-304. In: Neil, R.B. (eds.). Advances in photosynthesis. Vol.5. Photosynthesis and the environment. Kluwer Academic Publishers, Dordrecht, The Netherlands.

FAO-UNESCO. 1990. Soil map of the world. Revised legend. World Resources. Report 60. FAO, Rome, Italy.

Henriet, J., G.A. van Ek, S.F. Blade, and B.B. Singh. 1997. Quantitative assessment of traditional cropping systems in Sudan savanna of northern Nigeria. I. Rapid survey of prevalent cropping systems. Samaru J. Agr. Res. 14:37-45.

Karikari, S.K. and G. Molatakgosi. 1999. Response of cowpea [Vigna unguiculata (L.) Walp] varieties to leaf harvesting in Botswana. UNISWA J. Agr. 8:5-11.

Midya, A., K. Bhattacharjee, S.S. Ghose, and P. Banik. 2005. Deferred seeding of blackgram (Phaseolus mungo L.) in rice (Oryza sativa L.) field on yield advantages and smothering of weeds. J. Agron. Crop Sci. 191:195-201.

Mortimore, M.J., B.B. Singh, F. Harris, and S.B. Blade. 1997. Cowpea in traditional cropping systems, p. 99-113. In: Singh, B.B., D.R. Mohan Raj, K. Dashiell, and L.E.N. Jackai (eds.). Advances in cowpea research. Co-publication of International Institute of Tropical agriculture (IITA) and Japan International Center for Agricultural Sciences (JIRCAS), IITA, Ibadan, Nigeria.

Nyeko, P., G. Edwards-Jones, R.K. Day, and I. Ap-dewi. 2004. Effects of defoliation on growth characteristics and $\mathrm{N}, \mathrm{P}, \mathrm{K}$ content in 
an alder/maize agroforestry system. African Crop Science Journal 12:369-381.

Okalebo, J.R., K.W. Gathua, and P.L. Woomer. 2002. Laboratory methods of soil and plant analysis: A working Manual. 2nd Edition, Soil Science Society of East Africa Technical Publication No. 1, Marvel EPZ (Kenya) LTD, Nairobi, Kenya.

Rao, M.R. and M.N. Mathuva. 2000. Legumes for improving maize yields and income in semiarid Kenya. Agr. Ecosyst. Environ. 78:123-137.

Reda, F., J.A.C. Verkleij, and W.H.O. Ernst. 2005. Intercropping for the improvement of sorghum yield, soil fertility and striga control in the subsistence agriculture region of Tigray (Northern Ethiopia). J. Agron. Crop Sci. 191:10-19.
Rusinamhodzi, L.L., H.K. Murwira, and J. Nyamangara. 2006. Cotton-cowpea intercropping and its $\mathrm{N}_{2}$ fixation capacity improves yield of a subsequent maize crop under Zimbabwean rain-fed conditions. Plant Soil 287:327-336.

Saidi, M., M. Ngouajio, F.M. Itulya, and J. Ehler. 2007. Leaf harvesting initiation time and frequency affect biomass partitioning and yield of cowpea [Vigna unguiculata (L.) Walp]. Crop Sci. 47:1159-1166.

SAS Institute. 2002. SAS Release 9.1. SAS Institute, Cary, NC.

Singh, B.B., H.A. Ajeigbe, S.A. Tarawali, S Fernandez-Rivera, and M. Abubakar. 2003. Improving the production and utilization of cowpea as food and fodder. Field Crops Res $84: 169-177$.

Singh, B.B. and A.M. Emechebe. 1998. Increasing productivity of millet-cowpea intercropping systems, p. 88-95. In Emechebe, A.M., M.C. Ikwelle, O. Ajayi, M. Amino Kano, and A.B. Anosa (eds.). Pearl millet in Nigeria agriculture: Production, utilization and research priorities. Proc. of the Pre-season Planning Meeting for the Nationally Coordinated Research Programme for Pearl Millet, Maidiguri, 21-24 April 1997. Lake Chad Research Institute, Maiduguri, Nigeria.

Willey, R.N. 1979. Intercropping-Its importance and research needs. Part 1. Competition and yield advantages. Field Crop Abstracts 32:1-10. 